\title{
The "New Buffalo" Confronts a Pandemic: Implications of the COVID-19 Shock for the Indigenous Gaming Industry
}

\author{
Laurel Wheeler
}

This non-peer reviewed entry is published as part of the Critical Gambling Studies Blog. Visit an interactive version of this blog at: https://criticalgamblingstudies.blogspot.com/2021/01/the-new-

buffalo-confronts-pandemic.html

\begin{abstract}
"It's really pretty much crippled our tribal economy...The casinos are the bread and butter of our funding."

- Marlon WhiteEagle, president of the Ho-Chunk Nation (in Wisconsin State Journal, June 2020)

"Life and death...We're just going to write off 2020. There's no sense in trying to work under the delusion that we'll be able to claw back to normal life this year."

- Bryan Newland, tribal chairman of the Bay Mills Indian Community (in New York Times, May 2020)
\end{abstract}

\begin{abstract}
The COVID-19 pandemic is an economic shock that affects both the supply of and demand for goods and services. These effects are particularly profound in the hospitality and leisure sector, which includes the gaming industry. COVID-19 therefore has the potential to result in lasting damage to localities that depend on gaming revenues. For Indigenous gaming communities, the stakes are especially high. The Indigenous casino and gaming industry has been characterized as the coming of the "new buffalo"," a trope that alludes to the high levels of wealth enjoyed by bison-reliant communities in the Great Plains. Indeed, Indigenous gaming has been a valuable engine of economic growth for many communities across North America, but COVID-19 reveals this economic success to be a double-edged sword. The COVID-19 shock is now threatening to undermine an industry that has come to play a critical role in the physical and financial health of Indigenous gaming communities as well as in their capacity to exercise their right to self-determination.
\end{abstract}

Click below to listen to an interview with Joseph P Kalt, Co-director of the Harvard Project on American Indian Economic Development: "COVID-19 has closed tribal casinos and cut off other vital revenue sources"

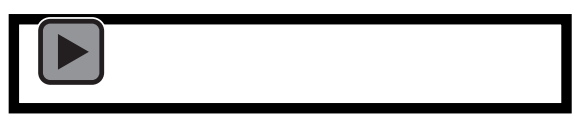

${ }^{1}$ See, for example, Lane (1995). As Cattelino (2008) points out, the "new buffalo" motif falls short in some respects. Importantly, the imagery inaccurately suggests that entrance into the casino and gaming industry is a passive action, something that "acts upon" Indigenous communities, rather than an action taken by Indigenous communities based on economic, political, and cultural incentives (p. 29). 


\section{Critical Gambling Studies Blog}

\section{Two Economic Shocks in One Pandemic}

More than one year after the novel coronavirus was first identified in humans, nations across the globe are experiencing a second wave of COVID-19 infections. In many places, this second wave threatens to be more injurious than the first, putting additional stress on already-weakened health care systems against the backdrop of an economic downturn. In an effort to slow the spread of the virus, local and national governments across North and South America, Asia, and Europe are instituting another series of restrictions on travel, activities, and gatherings. Inevitably, each new set of COVID-19-related restrictions renews debate about how to manage a health crisis and an economic crisis simultaneously.

From an economic standpoint, COVID-19 represents a severe, unanticipated shock with the particularly pernicious feature of affecting both supply and demand. Restrictions implemented to benefit public health come at the cost of production. Lockdowns that prevent workers from doing their jobs and social distancing measures that force businesses to close are examples of shocks that affect the supply of goods and services. But the COVID-19 pandemic is not only a short-run supply shock that comes and goes with the tightening and relaxing of restrictions. We now know that COVID-19 initially emerged as a supply shock but later led to an even larger demand shock (Guerrieri et al., 2020). A demand shock is anything that affects consumers' ability or willingness to purchase goods and services at a given price. As unemployment rises and consumers cut back on spending, demand for goods and services continues to plummet. The dual nature of this economic shock is rare, perhaps most often associated with natural disasters.

\section{The Casino and Gaming Industry takes a Direct Hit}

Although the COVID-19 shock pervades large swaths of the economy, it does not affect all sectors equally. At the start of the pandemic, economists began to make predictions about sectoral vulnerability to the COVID-19 shock (see, for example, the analysis by Mark Zandi, chief economist at Moody's). The consensus view was that the leisure and hospitality sector, characterized by face-to-face interaction and close physical proximity, would be among the most "at-risk." This is compared with the finance, insurance, or health care sectors, which were generally regarded to be shielded from the worst damage. Those predictions were borne out in the early months of the pandemic. Estimates using data from the United States indicate that the initial damage to the leisure and hospitality sector dwarfed the damage to other sectors, both in terms of supply and demand effects (see Figure 1). And situated squarely within the leisure and hospitality sector is the casino and gaming industry. 
Figure 1: Shock Decomposition for April 2020

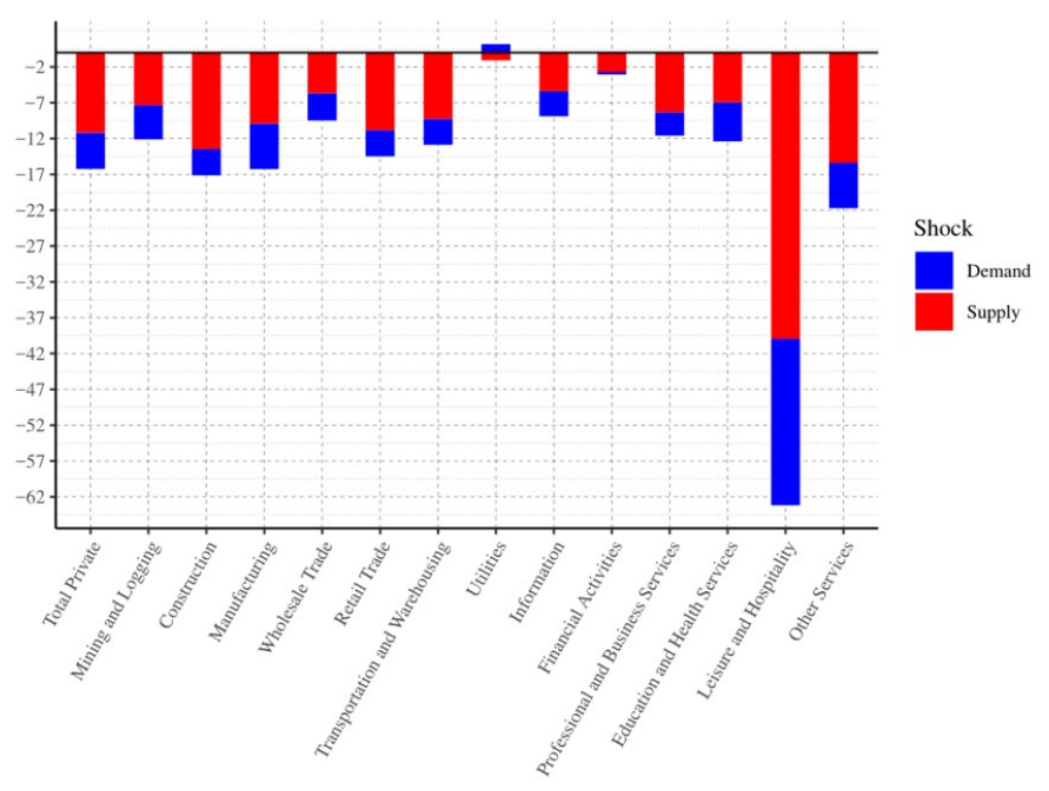

Notes: Estimated labor demand and supply shocks for different sectors were generated by Brinca et al. (2020) using an econometric model and April data from the U.S. Bureau of Labor Statistics. The sum of the red and blue bars is the percentage point change in the growth rate of hours worked relative to historical averages. The size of the red bar relative to the blue bar shows the importance of supply shocks relative to demand shocks. Graph and estimates produced by Brinca et al. (2020). Figure accessible at: https://voxeu.org/article/decomposing-demand-and-supply-shocks-during-covid-19.

In March 2020, S\&P Global Market Intelligence identified the casino and gaming industry as one of five industries most at risk of default in the United States. At the time, casinos across the world were closing their doors as governments tried to buy time to develop a cohesive response to a novel disease. In a 72hour period in March, Canada shut down almost all of its 114 casinos (Stevens, 2020). Those closures corresponded to millions of dollars in lost revenue in several provinces, including Manitoba and Quebec. Across the border, casino closures in the United States contributed to second quarter gross revenue losses measuring in the billions of dollars (American Gaming Association, 2020).

As you can see from Figure 2, the near-complete shutdown of the casino and gaming industry was relatively short lived. The majority of gaming properties in North America had re-opened by the end of the second quarter of 2020. The September update posted by S\&P Global Market Intelligence had removed the casino and gaming industry from their list of five industries most likely to default. But that doesn't mean the gaming industry is out of the woods yet. The pandemic's second wave is responsible for another round of closures. And until the macro economy improves and the inherent risk associated with being in close proximity to other people is mitigated, demand for traditional gaming options like casinos is likely to remain below 2019 levels. $^{2}$

\footnotetext{
${ }^{2}$ This is, of course, abstracting away from non-traditional options such as online gambling.
} 


\section{Critical Gambling Studies Blog}

Figure 2: Open United States and Canadian Gaming Properties by Date

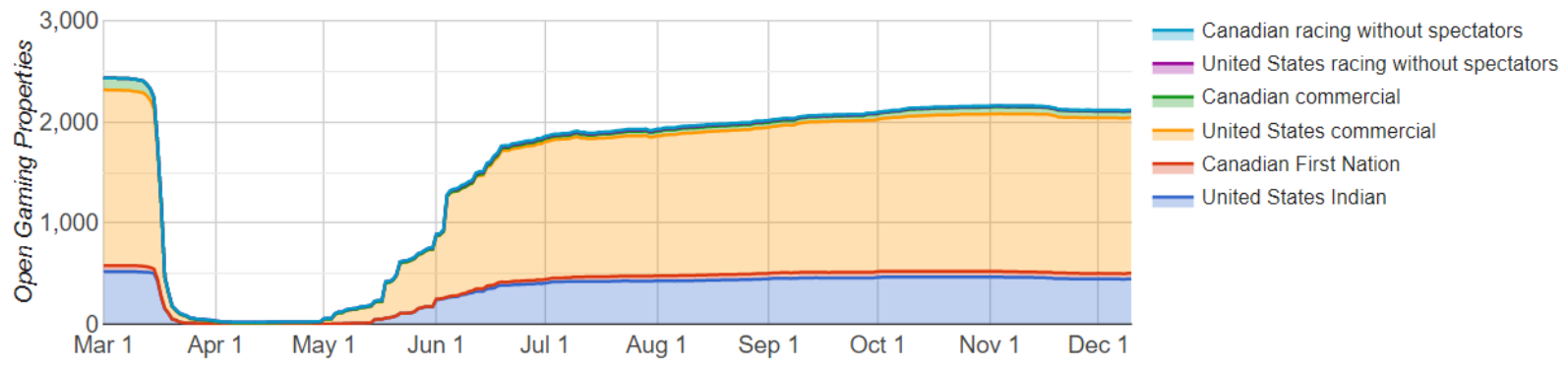

Notes: This interactive map is continually updated by Casino City's GamingDirectory.com and can be accessed at https://www.gamingdirectory.com/covid-19/11242020/\#map

We should care about the economic damage to the casino and gaming industry not only because we care about the industry, but also because we care about the communities that depend on it. Localities that rely heavily on gaming will be disproportionately affected by the COVID-19 shock. If these places lack diversification in their industrial base, they are left with no insurance against the shock, leading to widespread furloughs, unemployment, and lost wages within the community. With this concern in mind, The Brookings Institute conducted an analysis that ranked metropolitan areas in the United States by exposure to the economic effects of COVID-19 based on the share of jobs in high-risk industries (see Figure 3). Two of the top five most exposed metropolitan areas are among the world's most prominent casino cities: Atlantic City and Las Vegas.

Figure 3: Share of Jobs in Industries at High Risk from COVID-19 across the United States

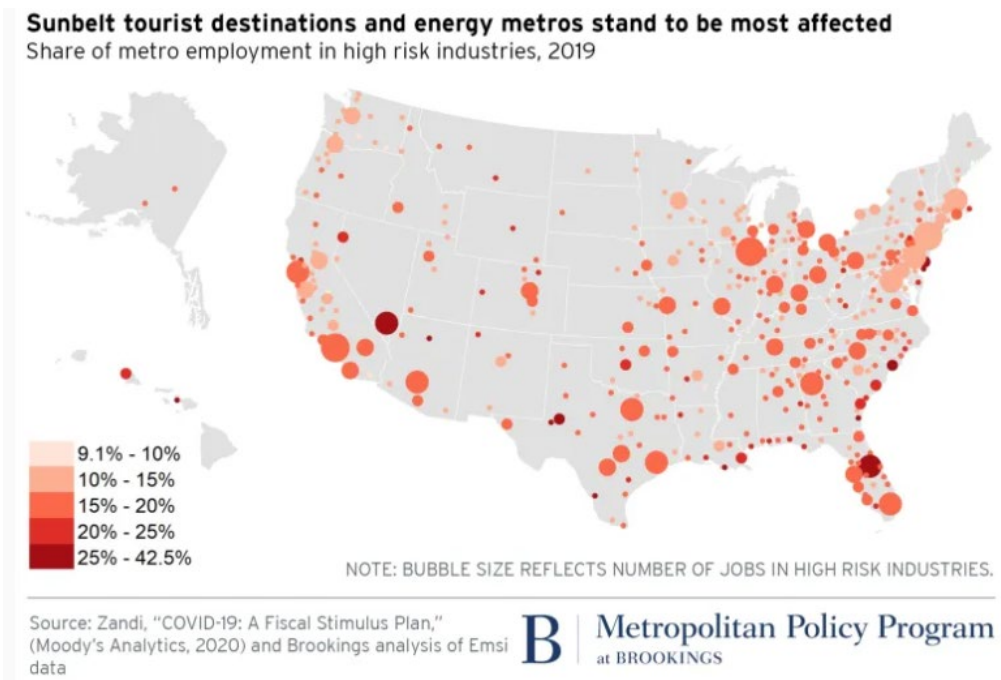

Notes: Map created by the Brookings Institute using Zandi (2020) definitions of "at-risk" industries. The figure can be accessed at: https://www.brookings.edu/blog/the-avenue/2020/03/17/the-places-a-covid-19-recession-will-likely-hit-hardest/ 


\section{Critical Gambling Studies Blog}

\section{The Economics of Indigenous Gaming}

Counted among the localities that specialize in the casino and gaming industry are many Indigenous communities across North America. The 1988 passage of the Indian Gaming Regulatory Act gave rise to a rapid proliferation of gaming facilities on federal reservations across the United States (see Figure 4). Today, more than 400 casinos operate on reservations in 29 states, generating gross revenues that exceed \$30 billion annually (National Indian Gaming Commission, 2020). Many tribal governments have invested heavily in the casino and gaming industry. By and large, those investments have paid off. Although experiences have not been uniform, most gaming communities have benefited from sustained revenues, which they have invested in a range of anti-poverty programs and tribal services (Akee et al., 2015). For example, Cattelino (2010) details how the Florida Seminoles allocate their gaming revenues to health care and education infrastructure, cultural programs, and economic diversification projects ranging from cattle ranching to venture capitalism. The Indigenous gaming industry in Canada is much smaller in scale but nonetheless important to the First Nations that operate 19 for-profit and charitable casinos, together generating more than \$1 billion in gross revenue annually (Belanger, 2014).

\section{Figure 4: The Evolution of Indigenous Gaming in the United States, 1990-2014}
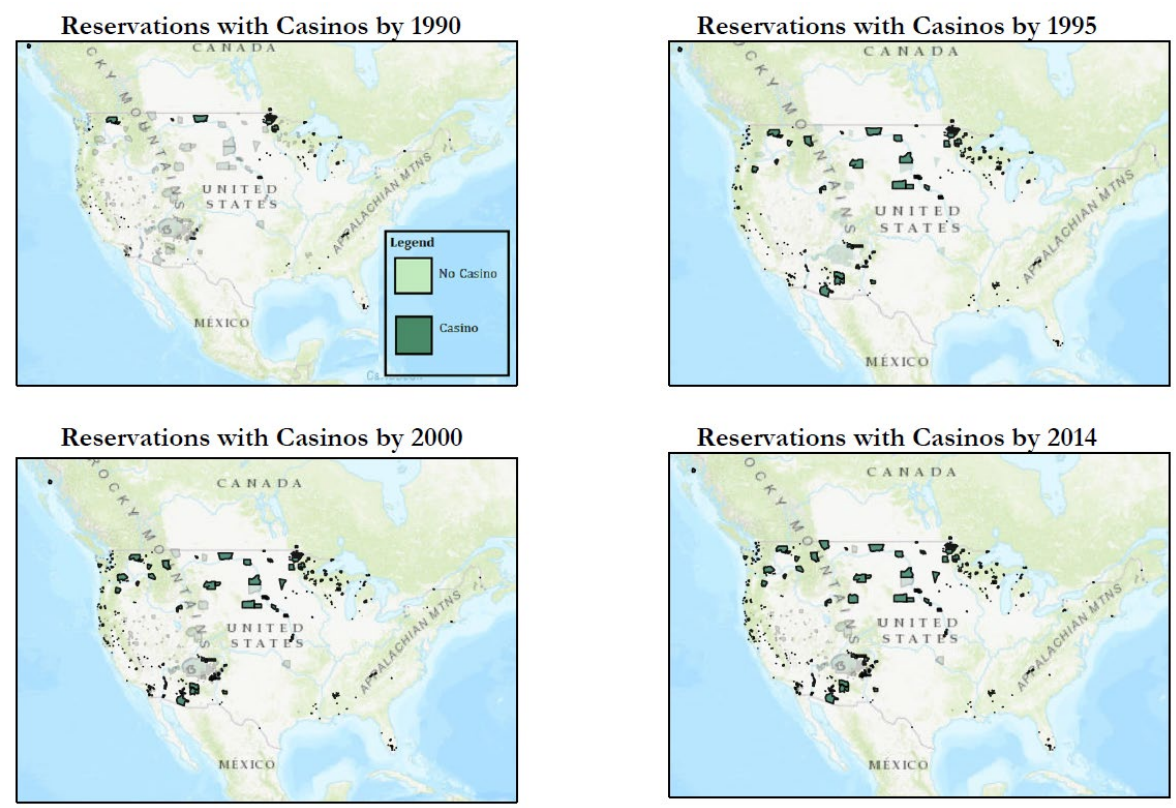

Notes: Author's own production using Census reservation shapefiles and data on casino openings on federally recognized reservations across the United States (Wheeler, 2019).

\section{The Vulnerabilities of Casino-Reliance}

Particularly in the early days, Indigenous gaming was hailed as an economic development panacea. It was described as "the new buffalo," drawing comparison to the historical importance of the North American bison to many Indigenous communities throughout the Plains, the Northwest, and the Rocky 


\section{Critical Gambling Studies Blog}

Mountains. For 10,000 years, these communities relied on bison for food, clothing, blankets, and trade. The bison was the backbone of their economies and a source of prosperity. Comparing Indigenous gaming to the North American bison underscores the perceived importance of the industry to the prosperity of Indigenous communities. It also raises questions about the vulnerability of gaming communities to economic shocks. European settlers hunted the bison to near-extinction in the late $19^{\text {th }}$ century, devastating the economies of the bison-reliant communities. Economists at the University of Victoria have shown that the slaughter of the bison was so destructive to bison-reliant communities that the negative effects persist to this day in the form of both economic and physical outcomes (Feir et al., 2019). ${ }^{3}$ It would be inappropriate to stretch the "new buffalo" analogy to generate predictions about the impact of the COVID-19 shock on casino-reliant communities. ${ }^{4}$ Nevertheless, the destruction of the bison illustrates the inherent economic vulnerabilities associated with lack of diversification.

The shuttering of tribal casinos in the United States between March and May 2020 resulted in 300,000 people out of work, $\$ 997$ million in lost wages, and approximately $\$ 4.4$ billion in lost economic activity overall (Meister Economic Consulting, 2020). Indigenous casinos employ members of the community as well as non-members, so the economic effects of casino closures extend beyond the boundaries of the reservation or reserve. Most worrying is the effect of lost casino revenue on Indigenous gaming communities. Unlike state or local governments, tribal governments have no tax base. For the HoChunk Nation, the Oneida Nation, and many other gaming communities, casino revenues comprise the vast majority of the tribal government's operating budget. Marlon WhiteEagle, president of the HoChunk Nation, described the casino closures as "crippl[ing]" to their tribal economy (Wisconsin State Journal, 2020). In the embedded interview at the top of this post, Joseph Kalt, Co-director of the Harvard Project on American Indian Economic Development, tells of the pervasiveness of these debilitating effects. He explains that, due to COVID-19, Indigenous gaming communities "run a risk of reversing about 30 years of slow, but steady progress."

\section{The COVID-19 Shock Wave: Beyond Economics}

The COVID-19 threat to progress is not only an economic concern. Indigenous communities are facing an acute public health crisis in the midst of a financial crisis. We've seen that racially marginalized communities experience disproportionately high rates of infection and mortality, a phenomenon that has been linked to social inequities. Many Indigenous communities across North America are particularly vulnerable to COVID-19 due to overcrowded living conditions, underfunded health care systems, and the prevalence of pre-existing health conditions. The high incidence of COVID-19 in Indigenous populations has generated real concern about loss of culture and traditions, in particular as Indigenous communities lose more of their Elders to the effects of the virus.

Among Indigenous communities involved in the casino and gaming industry, COVID-19 may pose an additional set of challenges related to self-determination, or the collective right to "freely pursue their

\footnotetext{
3 Physical measures such as height are often used as non-economic indicators of well-being. Feir et al. (2019) find that the descendants of bison-reliant peoples are shorter due to the slaughter of the bison, suggesting that their well-being was impacted through a mechanism such as malnutrition.

${ }^{4}$ The slaughter of the bison did not only affect bison-reliant communities through economic channels. Bison were integrated into the fabric of Indigenous society. The intentional destruction of the bison was both an economic act and a socio-cultural one.
} 


\section{Critical Gambling Studies Blog}

economic, social and cultural development" (Article 1 of the International Covenant on Civil and Political Rights). Although the sovereignty of Indigenous nations is inherent, settler colonialism in North America has acted to subvert it, either by design or by circumstance. ${ }^{5}$ Within this context, Indigenous gaming emerged, strengthening the means to exercise sovereignty in law and in practice (Belanger et al., 2013). For many Indigenous communities, entrance into the casino and gaming industry is an assertion of sovereignty - an affirmation of their right to govern issues related to economic development on their homelands, even when those activities are prohibited by law elsewhere. ${ }^{6}$ In the longer run, economic progress through gaming strengthens political power and the ability to self-govern effectively. Although the relationship between economic growth and sovereignty is complex, ${ }^{7}$ one thing is clear: the COVID-19 shock has implications that extend well beyond revenue loss for Indigenous gaming communities. In contrast, gaming cities like Las Vegas and Atlantic City may be susceptible to severe economic ramifications but they are unlikely to endure domestic political ramifications.

Throughout the pandemic, Indigenous communities have leveraged their sovereign status to enact regulations and implement policies to protect their citizens. Even in the absence of state or provincial safety measures, Indigenous nations have implemented curfews and lockdowns, set up call centers and incident command systems, and created highway checkpoints. By the same token, sovereignty gives Indigenous nations the option to forgo safety measures that have been put in place by the state, provincial, or federal government. Indigenous communities may decide to keep their casinos open even when other commercial casinos have been forced to close. This has left many gaming communities with a difficult choice between the health of their community members and their economic stability. Yet, in reality, when casino revenues fund tribal services like health care, are these options separable?

\section{The Road Ahead}

The COVID-19 pandemic further exposes the known precariousness of an economy that lacks diversification. Any locality that is heavily reliant on the casino and gaming industry is likely to be particularly hard-hit by the COVID-19 shock. Without being able to observe the economic portfolios of all Indigenous gaming communities, it seems safe to say that many Indigenous communities in North America have come to depend on the industry that has been called "the new buffalo." On the surface, the worrying implication of the "new buffalo" analogy is that the COVID-19 shock will have severe consequences for casino-reliant communities, just as the slaughter of the bison had for bison-reliant communities. However, deeper analysis shows where the parallelism ends between the bison and the casinos. Bison were more than a source of livelihood. They played a central role in the traditions and

\footnotetext{
${ }^{5}$ As one example, U.S. federal policy in the Termination Era (from the 1940s-1960s) sought to forcibly assimilate Indigenous people by eradicating federal reservations, terminating treaty obligations to Indigenous nations, and ending government aid programs.

6 This perspective is more likely to be relevant in the U.S. context than the Canadian context. Canada does not recognize that First Nations have a right to participate in the casino and gaming industry in the way that the United States does (Marshall, 2019). Instead, pursuant to the 1985 Criminal Code of Canada, First Nations must enter into agreements with provinces.

7 In fact, economic growth may simultaneously strengthen the means to exercise sovereignty and undermine sovereignty (Cattelino, 2010). For example, the U.S. federal government used economic strength as way to target tribes for Termination Era policies, based on the idea that the communities with the strongest economies no longer needed a collective agreement with the federal government. Cattelino calls this approach "need-based sovereignty," which puts Indigenous communities in the untenable position of being unable to exercise sovereignty without economic power and yet challenged about the legitimacy of their sovereignty given economic power.
} 
culture of the peoples who depended on them. In contrast, as described by Manitowabi (2017), casinos are economic tools with tenuous connections to culture. ${ }^{8}$

So what is the future of the Indigenous gaming industry in the wake of the COVID-19 pandemic? It may be too early to say. But if history is any indication, there's reason to remain optimistic. In 2005, Hurricane Katrina devastated the Mississippi Gulf Coast, another region of importance to the casino and gaming industry. Casinos along the Gulf Coast closed in anticipation of the storm. Many remained closed in the aftermath, after incurring major structural damage (Ewing et al., 2009). As with COVID-19, communities had lost their major source of employment overnight. But after announcing their plans to rebuild, casinos proved to be "an anchor" for regional recovery efforts (p. 2). Perhaps casinos will be at the forefront of COVID-19 recovery as well.

For many Indigenous communities coming out of the COVID-19 pandemic, the road ahead will be winding. Indigenous peoples across North America have a long history of resilience in the face of extreme adversity. That resilience derives from adaptation. Feir et al. (2019) argue that bison-reliant communities suffered persistent, negative economic and health outcomes in large part because federal restrictions designed to protect settler-colonial interests prevented Indigenous peoples from adjusting to new conditions. ${ }^{9}$ One lesson for the present day is that Indigenous communities may be able to absorb the COVID-19 shock by continuing to assert their sovereignty to develop individualized strategies to respond to the COVID-19 pandemic. Because of the nature of the COVID-19 shock, the most effective strategies will target both demand and supply. And in the long-run, both gaming and non-gaming communities should continue to diversify their local economies as insurance against future shocks.

Laurel Wheeler is an Assistant Professor in the Department of Economics at the University of Alberta. As a labor and development economist, her research addresses issues of poverty and inequality in lowincome countries and in North America.

\section{References:}

Akee, R.K.Q, Spilde, K.A., and Taylor, J.B. (2015). The Indian Gaming Regulatory Act and its effects on American Indian economic development. Journal of Economic Perspectives, 29(3): 185-208.

American Gaming Association. (June 2020). Commercial gaming revenue tracker. Retrieved from: https://www.americangaming.org/wp-content/uploads/2020/08/2020-Q2-Commercial-GamingRevenue-Tracker.pdf

The Atlantic. (May 2016). 'Kill every buffalo you can! Every buffalo dead is an Indian gone.' Retrieved from: https://www.theatlantic.com/national/archive/2016/05/the-buffalo-killers/482349

\footnotetext{
8 Through a case study of Casino Rama, Manitowabi (2017) illustrates how Indigenous casinos may employ cultural stereotypes of indigeneity for marketing purposes rather than for the purposes of genuine cultural expression.

${ }_{9}^{9}$ Specifically, Feir et al. (2019) suggest that federal restrictions on mobility and economic diversification precluded communities from making adjustments to economic shocks.
} 


\section{Critical Gambling Studies Blog}

Belanger, Y.D. (2014). Are Canadian First Nations casinos providing maximum benefits? Appraising First Nations casinos in Ontario, Saskatchewan, and Alberta, 2006-2010. UNLV Gaming Research \& Review Journal, 18(2): 65-84.

Belanger, Y.D., Williams, R.J., and Arthur, J.N. (2013). Manufacturing regional disparity in the pursuit of economic equality: Alberta's First Nations gaming policy, 2006-2010. The Canadian Geographer, 57(1): 11-30.

Brinca, P, Duarte, J. B. and Faria-e-Castro, M. (2020), "Measuring sectoral supply and demand shocks during COVID-19", Covid Economics, Issue 20, London: CEPR Press.

The Brookings Institute. (March 2020). The places a COVID-19 recession will likely hit hardest. Retrieved from: https://www.brookings.edu/blog/the-avenue/2020/03/17/the-places-a-covid-19-recession-willlikely-hit-hardest/

Capital \& Main. (2020). Tribal casinos weigh dueling risks of COVID-19, economic ruin. Retrieved from: https://capitalandmain.com/tribal-casinos-weigh-risks-of-covid-19-economic-ruin-0823.

Cattelino, J. (2008). High stakes: Florida Seminole gaming and sovereignty. Duke University Press: Durham, N.C.

Cattelino, J. (2010). The double bind of American Indian need-based sovereignty. Cultural Anthropology, 25(2): 235-262.

Centers for Disease Control and Prevention (August 2020). COVID-19 among American Indian and Alaska Native Persons - 23 States, January 31 - July 3, 2020. Retrieved from:

https://www.cdc.gov/mmwr/volumes/6g/wr/mm6934e1.htm

Chicago Booth Review. (2020). How COVID-19 shocked both supply and demand. Retrieved from: https://review.chicagobooth.edu/economics/2020/article/how-covid-19-shocked-both-supply-anddemand

Ewing, B.T., Kruse, J.B., and Sutter, D. (2009). Hurricane Katrina and economic loss. Journal of Business Valuation and Economic Loss Analysis, 4(2): 1.

Feir, D., Gillezeau, R., and Jones, M. E. C. (2019). The slaughter of the bison and reversal of fortunes on the great plains. No. 1-2019. Federal Reserve Bank of Minneapolis.

Harvard Kennedy Schooo.I (2020). COVID-19 has closed tribal casinos and cut off other vital revenue sources - Joseph Kalt. Retrieved from:

https://www.hks.harvard.edu/centers/mrcbg/programs/growthpolicy/covid-19-has-closed-tribalcasinos-and-cut-other-vital-revenue

Guerrieri, V., Lorenzoni, G., Straub, L., and Werning, I. (2020). "Macroeconomic Implications of COVID19: Can Negative Supply Shocks Cause Demand Shortages?" Working paper, April 2020

Lane, A. I. (1995). Return of the buffalo: The story behind America's Indian gaming explosion. Greenwood Publishing Group.

Manitowabi, D. (2011). Casino Rama: First Nations self-determination, neoliberal solution, or partial middle ground? (Y.D. Belanger, Ed.) Univ of Manitoba Press. 


\section{Critical Gambling Studies Blog}

Manitowabi, D. (2017). Masking Anishinaabe Bimaadiziwin. Uncovering cultural representation at Casino Rama. In B. Gercken \& J. Pelletier (Eds.), Gaming, the noble savage, and the not-so-new Indian (pp. 105-118).

Marshall, M. (2019). First Nations gaming in Canada: Navigating the labyrinth. Gaming Law Review, 23(8), 559-571.

Meister Economic Consulting. (2020). Coronavirus impact on tribal gaming. Retrieved from: http://www.meistereconomics.com/coronavirus-impact-on-tribal-gaming

National Indian Gaming Commission. (2020). Gross gaming revenue reports. Retrieved from: https://www.nigc.gov/commission/gaming-revenue-reports

Native Governance Center. (2020). How does tribal sovereignty operate during COVID-19? Retrieved from: https://nativegov.org/tribal-sovereignty-and-covid-19/

The New York Times. (2020). Social inequities explain racial gaps in pandemic, studies find. Retrieved from: https://www.nytimes.com/2020/12/og/health/coronavirus-black-hispanic.html

The New York Times. (May 2020). Tribal nations face most severe crisis in decades as the coronavirus closes casinos. Retrieved from: https://www.nytimes.com/2020/05/11/us/coronavirus-native-americansindian-country.html

NPR. (May 2020). Navajo Nation loses Elders and tradition to COVID-19. Retrieved from: https://www.npr.org/2020/05/31/865540308/navajo-nation-loses-elders-and-tradition-to-covid-19

Reuters. (June 2020). Loss of Canada Elders to coronavirus threatens Indigenous culture. Retrieved from: https://www.reuters.com/article/us-health-coronavirus-canada-indigenous/loss-of-canada-elders-tocoronavirus-threatens-indigenous-culture-idUSKBN2382D4

S\&P Market Intelligence. (March 2020). Industries most and least impacted by COVID-19 from a probability of default perspective - March 2020 Update. Retrieved from:

https://www.spglobal.com/marketintelligence/en/news-insights/blog/industries-most-and-leastimpacted-by-covid-19-from-a-probability-of-default-perspective-march-2020-update

S\&P Market Intelligence. (September 2020). Industries most and least impacted by COVID-19 from a probability of default perspective - September 2020 Update. Retrieved from:

spglobal.com/marketintelligence/en/news-insights/blog/industries-most-and-least-impacted-bycovid19-from-a-probability-of-default-perspective-september-2020-update

Stevens, Rhys. (March 2020). The impact of COVID-19 on gambling availability. Retrieved from: https://abgamblinginstitute.ca/files/abgamblinginstitute/canada_commercial_gambling_closures_covi d-19_by_province_march_25_2020.pdf

The United Nations Human Rights Office of the High Commissioner. International covenant on civil and political human rights. Retrieved from:

https://www.ohchr.org/EN/Professionallnterest/Pages/CCPR.aspx

Vox. (2020). The coronavirus is exacerbating vulnerabilities Native communities already face. Retrieved from: https://www.vox.com/2020/3/25/2119266g/coronavirus-native-americans-indians 


\section{Critical Gambling Studies Blog}

Vox EU. (2020). Decomposing demand and supply shocks during COVID-19. Retrieved from:

https://voxeu.org/article/decomposing-demand-and-supply-shocks-during-covid-19

Wheeler, L. (2019). Property rights, place-based policies, and economic development. US Census Bureau working paper series, Center for Economic Studies.

The Wisconsin State Journal. (2020). Tribal governments 'crippled' by lost gambling revenue during

COVID-19 pandemic. Retrieved from: https://madison.com/wsj/business/tribal-governments-crippled-

by-lost-gambling-revenue-during-covid-19-pandemic/article_67265dbg-1dfa-53c4-b78c-

5e46273781ge.html

Zandi, M. (March 2020). COVID-19: A Fiscal Stimulus Plan. Retrieved from:

https://www.economy.com/economicview/analysis/378644/COVID19-A-Fiscal-Stimulus-Plan 